\title{
Half a Century of Research on Membrane-Containing Bacteriophages: Bringing New Concepts to Modern Virology
}

\author{
Sari Mäntynen ${ }^{1,2}$, Lotta-Riina Sundberg ${ }^{1}$, Hanna M. Oksanen ${ }^{3, * \mathbb{C}}$ and Minna M. Poranen ${ }^{3, *}$ \\ 1 Center of Excellence in Biological Interactions, Department of Biological and Environmental Science and \\ Nanoscience Center, University of Jyväskylä, FI-40014 Jyväskylä, Finland; ssmantynen@ucdavis.edu (S.M.); \\ lotta-riina.sundberg@jyu.fi (L.-R.S.) \\ 2 Department of Microbiology and Molecular Genetics, University of California, Davis, CA 95616, USA \\ 3 Molecular and Integrative Biosciences Research Programme, Faculty of Biological and Environmental \\ Sciences, University of Helsinki, FI-00014 Helsinki, Finland \\ * Correspondence: hanna.oksanen@helsinki.fi (H.M.O.); minna.poranen@helsinki.fi (M.M.P.); \\ Tel.: +358-2941-59104 (H.M.O.); +358-2941-59106 (M.M.P.)
}

Received: 20 December 2018; Accepted: 16 January 2019; Published: 18 January 2019

\begin{abstract}
Half a century of research on membrane-containing phages has had a major impact on virology, providing new insights into virus diversity, evolution and ecological importance. The recent revolutionary technical advances in imaging, sequencing and lipid analysis have significantly boosted the depth and volume of knowledge on these viruses. This has resulted in new concepts of virus assembly, understanding of virion stability and dynamics, and the description of novel processes for viral genome packaging and membrane-driven genome delivery to the host. The detailed analyses of such processes have given novel insights into DNA transport across the protein-rich lipid bilayer and the transformation of spherical membrane structures into tubular nanotubes, resulting in the description of unexpectedly dynamic functions of the membrane structures. Membrane-containing phages have provided a framework for understanding virus evolution. The original observation on membrane-containing bacteriophage PRD1 and human pathogenic adenovirus has been fundamental in delineating the concept of "viral lineages", postulating that the fold of the major capsid protein can be used as an evolutionary fingerprint to trace long-distance evolutionary relationships that are unrecognizable from the primary sequences. This has brought the early evolutionary paths of certain eukaryotic, bacterial, and archaeal viruses together, and potentially enables the reorganization of the nearly immeasurable virus population $\left(\sim 1 \times 10^{31}\right)$ on Earth into a reasonably low number of groups representing different architectural principles. In addition, the research on membrane-containing phages can support the development of novel tools and strategies for human therapy and crop protection.
\end{abstract}

Keywords: Tectiviridae; Cystoviridae; Corticoviridae; Plasmaviridae; lipid-containing bacteriophage; virus-host interaction; virus evolution

\section{Introduction}

Membranes composed of lipid bilayers with embedded proteins are essential for all cellular life forms. Many viruses parasitizing their host cells possess membranes either as an outer envelope or as a capsid-enclosed internal membrane. Some of the most notorious human pathogens, such as human immunodeficiency virus, influenza virus and Zika virus, have lipid components in their virions. Lipid membranes are also commonly detected in archaeal viruses [1]. However, lipids have been considered to be a rare feature among bacterial viruses (bacteriophages, phages for short), existing 
in less than $4 \%$ of the described isolates [2,3]. Nevertheless, the number of membrane-containing phages in culture and sequence collections has increased significantly in recent years providing new perspectives on virus diversity. Moreover, the technical advances in imaging, sequencing and lipid analysis have notably increased knowledge of these viruses. Membrane-containing phages are now recognized as common bacterial parasites in various ecological niches, thus having a larger role in the microbial ecology than previously recognized [4-6]. From a molecular biology perspective, these viruses provide ideal model systems to study membrane biosynthesis, structure, and function. In this review, we will summarize the state-of-the-art on membrane-containing bacteriophages. We will give an overall view of this fascinating group of bacterial viruses with an emphasis on the new results and theories.

\section{Membrane-Containing Bacteriophages Form a Diverse Group of Biological Entities}

Bacteriophages are generally acknowledged as the most abundant group of biological entities on Earth, outnumbering their bacterial hosts by at least ten-fold [7]. The first membrane-containing phage, Pseudoalteromonas phage PM2, was isolated fifty years ago, in 1968, several decades after the discovery of phages [8]. Since then, additional membrane-containing phages have been isolated throughout the world from various sources, including rotting plants, seawater, freshwater and sewage ecosystems. They infect a wide range of bacterial strains of medical, economic and environmental importance (e.g., Escherichia coli, Pseudomonas syringae, Salmonella typhimurium and Bacillus anthracis). Some of these phage isolates have been characterized more comprehensively and subsequently classified into the families Corticoviridae, Cystoviridae, Plasmaviridae, Sphaerolipoviridae and Tectiviridae by the International Committee on Taxonomy of Viruses. Most of the recently described membrane-containing phages fit into the present taxa, but the need for new families and genera has also been recognized. The family "Autolykiviridae", comprising membrane-containing double-stranded (ds) DNA phages, is an example of such recently proposed taxa [6]. Flavobacterium phage FLiP represents another novel virus type that does not fit to any current taxa; the icosahedral protein capsid surrounding the internal membrane is uniquely combined in FLiP virions with a single-stranded (ss) DNA genome [9]. This discovery together with Salisaeta icosahedral phage 1 (SSIP-1), a membrane-containing phage with a genome sequence that hardly shares any similarity with those in the GenBank [10], demonstrates that membrane-containing phages are even more diverse than previously appreciated, and elucidates the importance of the isolation and characterization of new phages to gain a deeper understanding of the microbial diversity in various environmental niches.

Even though membrane-containing bacteriophages are relatively underrepresented among identified phage isolates, they form a remarkably diverse group differing in terms of virion morphologies, genome types and sequences as well as replication mechanisms. Some have highly complex virion structures with concentric protein and lipid layers, while others are merely proteinaceous lipid bags surrounding the genome. Moreover, both circular dsDNA and ssDNA genomes as well as linear dsDNA and dsRNA genomes exist (Table 1). Capsid-enclosed internal membrane-containing dsDNA phage PRD1 [11] and enveloped dsRNA phage phi6 [12] are among the best-characterized viral systems and the type members of the families Tectiviridae and Cystoviridae, respectively. Their life cycles have been comprehensively described and, consequently, the functions of membranes have also been well established for these phages.

Tailed bacteriophages, currently classified in the Caudovirales order, are the most abundant group of phages, outnumbering the known membrane-containing phages by over an order of magnitude. The success of the tailed virion morphology among bacterial viruses may be related to the efficiency of the tail devise in the process of bacterial cell envelope penetration. The fact that tailed virion morphologies are not known among viruses infecting wall-less eukaryotic cells supports this hypothesis. Furthermore, tailed phages with long contractile tails (myoviruses) generally have a relatively wide host range, which supports their reproduction in changing microbial communities [13]. The limited number of membrane-containing phage isolates in the previous studies could also partially 
be explained by their specific phenotypic characteristics that can make them subject to systematic loss in culture-based studies [6]. Firstly, membrane-containing phages are sensitive to chloroform, a reagent traditionally used in viral preparation to avoid bacterial contaminations $[6,14]$. Moreover, their low buoyant densities are outside the range commonly targeted when extracting phages from environmental samples using density gradient ultracentrifugation $[6,15,16]$. These factors should be considered when preparing samples for virus isolation and metagenomics to achieve a more complete view of the viral universe.

Table 1. Virus isolates of the membrane-containing bacteriophages with a complete genome sequence.

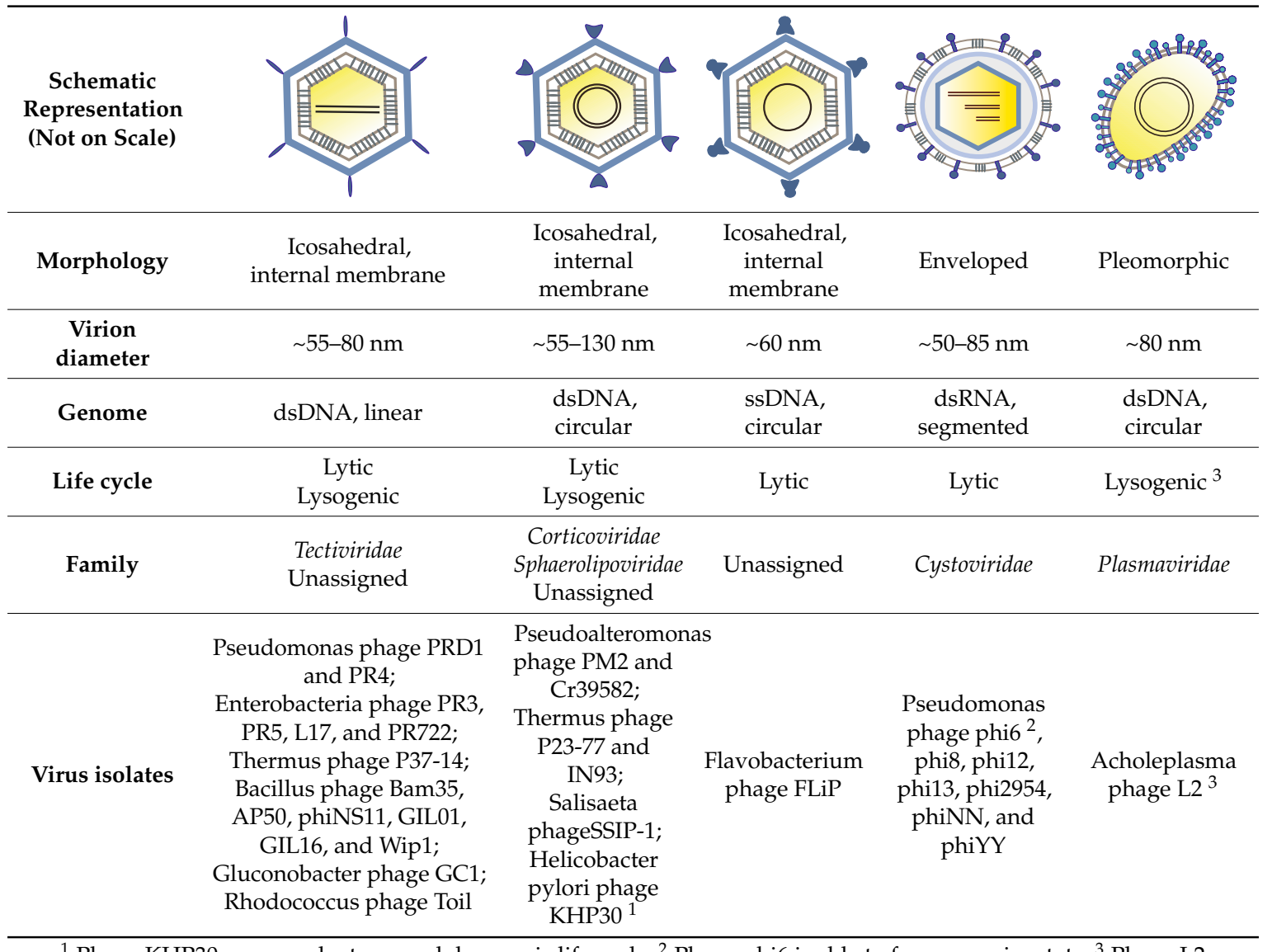

${ }^{1}$ Phage KHP30 may conduct a pseudolysogenic life cycle; ${ }^{2}$ Phage phi6 is able to form a carrier state; ${ }^{3}$ Phage L2 virions appear to be released by budding through the cell membrane, without lysing the host cell.

\section{Phage Lipids and Their Identification}

Bacteriophages do not carry inherent machinery for lipid biosynthesis, but their lipids are acquired from the host cytoplasmic membrane during virion assembly. Thus, the lipid composition of the phage reflects that of its host bacterium, at least to some extent. Bacterial membranes are primarily comprised of amphiphilic phospholipids. The most common lipid type is glycerophospholipid, in which two fatty acid side chains are linked to sn-glycerol-3-phosphate through ester linkages [17]. For instance, the major phospholipids of $E$. coli include zwitterionic phosphatidylethanolamine (75\% of the membrane), anionic phosphatidylglycerol (20\%) and cardiolipin (5\%) [17].

Host-derived lipids seem to exist in phages predominantly as bilayers (membranes), which are embedded with phage-encoded proteins. For instance, the internal membrane of PRD1 is a 50:50 mixture of protein and lipid [18]. Based on the location of the membrane, phages can be roughly divided into three subclasses: (i) viruses in which the membrane is located underneath an icosahedral protein capsid; (ii) viruses in which the membrane (envelope) is the outermost layer of the virion, surrounding an icosahedral protein capsid, and; (iii) viruses in which the genome is enclosed by a proteinaceous 
lipid vesicle with pleomorphic appearance without any rigid protein capsid (Table 1). The lipid composition of plasmaviruses largely follows the lipid composition of its host cell membrane [19]. However, in most cases the lipids are incorporated into the virion selectively. Mechanisms leading to this selective lipid acquisition have not been established, but some possible explanations have been suggested [20]. The phage may, for instance, obtain its lipids from a membrane microdomain (lipid raft) with a distinct lipid and protein composition. On the other hand, phage-encoded membrane proteins may also selectively attract specific lipids into the virion. Moreover, certain physico-chemical properties of lipids, such as the molecular shape and charge, can drive their selective incorporation into the highly curved phage membrane, especially in the viruses with an internal membrane and in the membrane areas close to the icosahedral five-fold axes. The different phospholipids are commonly distributed asymmetrically between the phage membrane leaflets [20-22]. This asymmetric distribution has been suggested to reflect the different shapes and charges of the phospholipids and lipid-protein interactions [20,22].

The sensitivity to chloroform (or other organic solvents) and detergents, as well as the low buoyant density of the virion $\left(\sim 1.3 \mathrm{~g} \mathrm{~cm}^{-3}\right.$ in $\left.\mathrm{CsCl}\right)$ are usually the first indications of a viral lipid component $[3,23]$. Purified virions can also be subjected to sodium dodecyl sulfate polyacrylamide gel electrophoresis and staining with lipophilic dye Sudan Black B to detect possible lipid moieties [3]. However, these are rather indirect ways to assay the presence of lipids. For instance, chloroform can also reduce the infectivity of virions, which lack membranes [24]. Also, the density of the virion can mislead, as in case of adenovirus $\left(1.31-1.36 \mathrm{~g} \mathrm{~cm}^{-3}\right.$ in $\left.\mathrm{CsCl}\right)$. Thus, further studies are needed to confirm the presence of lipids in virions and to determine their chemical compositions. Viral lipids are commonly extracted with organic solvents from highly purified virus particles and then subjected to thin layer chromatography, mass spectrometry (e.g., electrospray ionization) or nuclear magnetic resonance spectroscopy $[25,26]$. For such lipid work, highly purified viral particle material is a prerequisite to verify the presence of virus-specific lipids and to avoid misinterpreting the host-derived membrane impurities as virion components. In addition to traditional, preparative ultracentrifugation-based virus purification methods, monolithic chromatography and asymmetric flow field flow fractionation are currently available for the purification of membrane-containing phages $[27,28]$. Viral lipids can be directly detected from purified virus preparations by using matrix-assisted laser desorption ionization time-of-flight/mass spectrometry $[3,29,30]$. This technique enables the identification of lipid profiles from small amounts of viral material, without the need for a separate lipid extraction step.

The whole virus X-ray structures of phages PRD1 and PM2 $(4.2 \AA$ and $7.0 \AA$ resolution, respectively) allowed the detailed analysis of the internal membrane and the membrane-associated proteins $[22,31,32]$. Today, PRD1 is still the only virus with an internal membrane solved by X-ray crystallography at high resolution, reflecting the challenges faced by the crystallization of large complexes with membrane components. However, technical advances in electron cryomicroscopy (cryo-EM) have led to "resolution-revolution" and the structural characterization of viruses at atomic resolution, which can be conducted without the need for crystallization. The single particle cryo-EM, sub-tomogram averaging and localized reconstruction methods have also provided the means to resolve non-icosahedrally organised objects in virions, such as the membrane-anchored packaging complex and membranous genome delivery tube of PRD1 $[33,34]$ as well as the polymerase subunit and the dsRNA genome in phi6 procapsid [35] and nucleocapsid [36], respectively.

All in all, membrane-containing phages can be considered as composite systems in which nucleic acids, proteins and lipids combine in a unique way to produce infectious particles [37]. Interestingly, recent atomic force microscopic studies demonstrate that phage PRD1 is more resistant to mechanical stress compared to the majority of dsDNA icosahedral viruses that lack the membrane component [37]. It has been suggested that the coupling of a stiff and brittle protein shell and a soft and ductile membrane vesicle generates structural flexibility, which facilitates the different stages of the PRD1 
life cycle, including the mechanical protection role of the extracellular virion, DNA ejection via vesicle-to-tube transformation and virion assembly (see below for details).

\section{Significance of Membranes in Phage Life Cycle}

Viruses have evolved different strategies to utilize their membranes in infection. For instance, most enveloped viruses undergo membrane fusion to deliver their genomic material into the cell [38]. Upon adsorption to a host cell, phi6, and presumably other cystoviruses, merge their envelope with the outer membrane of their Gram-negative host bacterium using phage-encoded fusion protein $[39,40]$ (Figure 1a). The nucleocapsid surface shell, residing beneath the envelope, interacts with phospholipids of the host plasma membrane and induces the formation of cytoplasmic membrane invaginations. This process is dependent on the energized state of the host membrane and results in the delivery of the phi6 virion core into the host cell cytoplasm [41-43]. On the other hand, in the case of pleomorphic plasmaviruses, the fusion is assumed to take place between the virion envelope and the host cytoplasmic membrane, as Acholeplasma cells have no cell wall [44]. Interestingly, the capsid-enclosed internal membrane of the tectiviruses also has a dynamic role in virus entry. PRD1 and Bam35, infecting Gram-negative and Gram-positive bacteria, respectively, use their internal membrane vesicle to form a proteo-lipidic tube, which penetrates the cell envelope and provides a conduit for the passage of the linear dsDNA genome into the cell [34,45-47] (Figure 1b). The proteo-lipidic tube of tectiviruses forms only after receptor recognition. Binding to the receptor triggers de-capping of the vertices that leads to the loss of capsid-membrane interactions and ultimately protrusion of the tail tube, presumably from the same vertex used for packaging [34,46]. Mutations in several PRD1 membrane proteins inhibit the tube formation, suggesting their role in the membrane transformation [48]. Similarly, a proteinaceous tail structure forms and protrudes from the phage $\Phi \times 174$ virion only at the time of infection and is presumably used for ssDNA genome delivery [49]. For comparison, the proteinaceous DNA injecting machinery of tailed dsDNA phages (the order Caudovirales) is a permanent component of the virion and energy stored in the highly dense packaged genome is one of the major driving forces in the genome injection [50]. In contrast, the packaged PRD1 genome is not required for the tube formation [34], but the internal membrane vesicle has an active role in the viral genome ejection as recently described by cryo-electron tomography [46]. A similar entry mechanism has been proposed for other phages with an internal membrane vesicle enclosing a linear dsDNA genome [34]. However, different genome types impose divergent constraints on the DNA injection, presumably giving rise to variation in the viral entry mechanisms. For instance, phage PM2 has been suggested to transfer its circular, supercoiled dsDNA genome into the host by first removing its protein capsid and then fusing its internal membrane with the outer membrane of the Gram-negative host bacterium [51-53] (Figure 1c). 
(a)

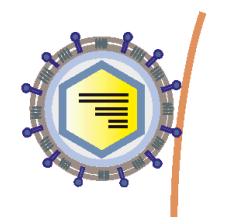

(b)

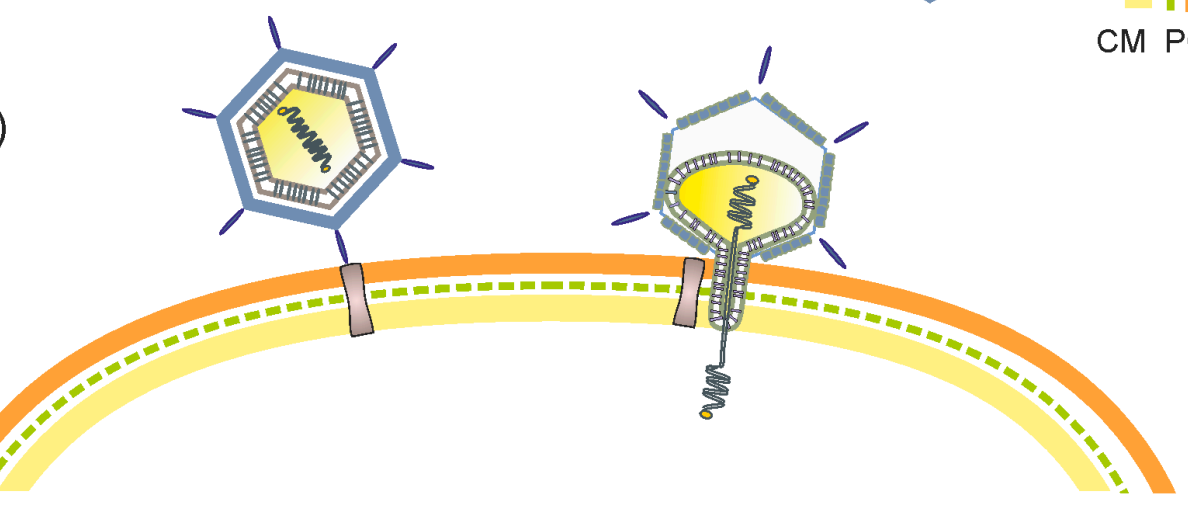

(c)
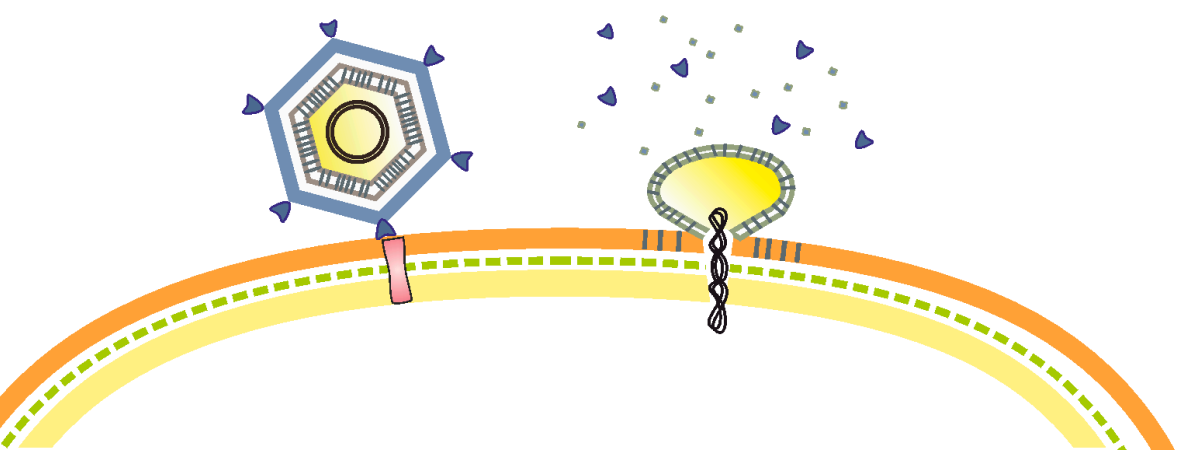

Figure 1. Entry mechanisms of membrane-containing phages. (a) Pseudomonas phage phi6. Phi6 attaches to a type IV pilus, which retracts and brings the virion into contact with the bacterial outer membrane. The viral membrane (envelope) fuses with the host outer membrane, releasing the nucleocapsid into periplasmic space. The peptidoglycan layer is digested by a virally-encoded lytic enzyme, after which the nucleocapsid enters the cytoplasm via an endocytic-like route. Finally, the nucleocapsid shell dissociates, releasing the phi6 virion core (polymerase complex). (b) Pseudomonas phage PRD1. Upon attachment to the host receptor, the internal membrane vesicle of phage PRD1 transforms into a proteo-lipidic tube, which traverses the cell envelope and provides a conduit for transferring the linear dsDNA genome into the cytoplasm. (c) Pseudoalteromonas phage PM2. It has been suggested that after phage PM2 binds to the host receptor, its protein capsid dissociates triggering the fusion between the internal membrane vesicle and the bacterial outer membrane and consequently the release of the circular dsDNA genome into the cell. CM, cytoplasmic membrane; PG, peptidoglycan layer; OM, outer membrane of the envelope in Gram-negative host bacterium. 
Lipids are incorporated into the newly synthesized virions by diverse mechanisms. Most enveloped viruses obtain their external membranes as the nucleocapsids bud through the cytoplasmic membrane or one of the intracellular membrane structures, such as the endoplasmic reticulum, intermediate compartment, Golgi or trans-Golgi network [54]. Virus egress by budding is a delicate way to release virions without disrupting the host cytoplasmic membrane. Budding has not been confirmed for any bacteriophage but is suggested as the mode of exit for pleomorphic plasmaviruses [44]. How cystoviruses acquire their envelope is not completely understood. It has been suggested that cytoplasmic membrane vesicles are formed during the phage phi6 life cycle and that these vesicles subsequently assemble on the newly synthesized nucleocapsid to produce enveloped viruses [55]. Virus-specific vesicles can also be produced in recombinant expression systems by co-expression of the proteins involved in the envelope biosynthesis [55,56]. The mature enveloped phi6 virions are ultimately released by phage-induced host cell lysis [57]. Some variation in the assembly pathways and exit strategies of membrane-containing phages presumably results from the differences in the host bacteria: whereas plasmaviruses only need to penetrate the cytoplasmic membrane, cystoviruses also have to cross the rigid peptidoglycan layer and the outer membrane of their Gram-negative host bacteria to deliver the transcriptionally active virion core into the cytoplasm. Host-derived vesicles can also be a prerequisite for the formation of internal membrane-containing phage virions. The assembly of phage PRD1 commences as soluble capsid proteins are synthesized in the cytoplasm and phage-encoded membrane proteins are recruited into the host cytoplasmic membrane [58]. A phage-specific membrane patch, enriched in phage-encoded non-structural protein $\mathrm{P} 10$, is pinched off from the cytoplasmic membrane [59], in a process mimicking the clathrin-mediated endocytosis of eukaryotic cells. The resulting vesicle most probably acts as a scaffold onto which capsid proteins are assembled, ultimately displacing protein P10 and leading to the formation of an empty procapsid. Packaging ATPase P9 powers the translocation of the linear dsDNA genome into the procapsid through the unique vertex structure spanning the phage membrane [33,60-63], and finally mature virions are released by lysis. For host cell lysis, PRD1 uses a holin-endolysin system [64], in which the virion-associated muramidase P15 [65,66] and holin P35 [64,67] degrade the cytoplasmic membrane and peptidoglycan layer in timely fashion. Two additional phage-encoded lysis proteins, P36 and P37, are needed under less favorable conditions [68]. A similar assembly mechanism has been suggested for other internal membrane-containing phages with a linear genome [33]. However, the assembly of phage PM2 does not presumably occur via an empty procapsid. Instead, the encapsidation of its supercoiled dsDNA may take place concurrently with the formation of the internal membrane-containing capsid shell [32]. It has been suggested that the PM2 transmembrane proteins, $\mathrm{P} 3$ and $\mathrm{P} 6$, act as templates for the correct registration of the capsomers on the membrane. This phage-specific area of the cytoplasmic membrane interacts with the nucleic acid, leading to the pinching off of the genome-containing membrane vesicles and ultimately to liberation of mature, internal membrane-containing virions from lysed cells. The host cell lysis commences as the phage-encoded protein, P17, punctuates the cytoplasmic membrane [69]. The peptidoglycan layer is most probably disrupted by host lytic factors, whereas another phage-encoded protein, P18, helps to disintegrate the outer membrane [69].

\section{Ecology and Evolution of Membrane-Containing Phages}

Recent virus isolation and metagenomics surveys suggest that membrane-containing phages are more numerous in nature than previously thought. For instance, newly discovered internal membrane-containing phages, Toil and GC1, with unique host ranges and lifestyle features have been proposed to belong to the family Tectiviridae [70,71]. In addition to these fully sequenced isolates, dozens of other putative tectiviruses infecting $B$. cereus have been discovered and partially sequenced [72,73]. Also, several cystoviruses have been isolated from varying habitats in globally distant locations, demonstrating that this virus type is a common bacterial parasite in certain terrestrial habitats [4,5,74-77]. Moreover, membrane-containing dsDNA phages, "autolykiviruses", were 
recently shown to be dominant parasites of ubiquitous marine bacteria of the family Vibrionaceae [6]. Furthermore, the recently found phage FLiP [9] demonstrates the potential of membrane-containing viruses in control of the abundant Flavobacterium hosts in freshwaters. These discoveries suggest that membrane-containing phages may play a relevant role in microbial ecology.

The assembly of membrane-containing phages is dependent on the host cell lipid pool that is utilized in a selective manner in many cases $[3,23]$. However, this lipid pool is not invariable as the bacterial membrane lipid composition is changing depending on ambient conditions, such as temperature, salinity, and $\mathrm{pH}$ [78]. Such changes in the lipid pools may influence phage-bacterium interactions in bacteria subjected to drastic environmental changes, e.g., in temperate latitudes.

Most known membrane-containing phages are virulent, but lysogenic cycles have also been described. For instance, the genus Alphatectivirus includes virulent phages infecting Gram-negative bacteria, whereas members of the genus Betatectivirus are temperate and replicate autonomously as linear plasmids in their Gram-positive host bacteria. Very recently, though, an alphaproteobacterial phage GC1 was isolated, which is the first described temperate tectivirus of Gram-negative bacteria [71]. Phage GC1 has been proposed to represent a new genus "Gammatectivirus" within the family Tectiviridae [71]. Lysogenic phages may have a significant role in the life cycle of their host bacteria. For instance, it has been shown that under laboratory conditions, tectiviral lysogeny has an effect on bacterial growth, the sporulation rate, biofilm formation and the swarming motility of B. thuringiensis, all of which are life traits involved in the survival and colonization of this bacterium in various environmental conditions [79]. Furthermore, virulent phage phi6 has been shown to be able to establish a carrier state [80], and such conditions can be boosted by introducing mutations to the gene encoding the lytic enzyme [81]. Similarly, a pseudolysogenic life cycle has been proposed for icosahedral internal membrane-containing phage KHP30 infecting Helicobacter pylori [82]. The frequency of carrier states or pseudolysogens in nature and consequently their role in the bacterial ecology and evolution are yet to be revealed [83]. Furthermore, although recent studies have identified several new phage resistance mechanisms [84], any possible bacterial resistance mechanisms related specifically to membrane-containing phages (e.g., restricting membrane acquisition) have not yet been identified.

At first glance, it is difficult to identify common features between different types of membrane-containing phages, which appear to be of polyphyletic origin [23]. However, high resolution structural data have provided surprising insights into the evolutionary trajectories of these viruses. Viruses can be classified into structure-based viral lineages based on common virion architectures and major capsid protein (MCP) folds [32,85-89]. The viral membrane components are not utilized as criteria as the presence of the membrane is not directly linked to the capsid protein fold. For now, there are four lineages, one of which is the so-called PRD1-adenovirus lineage. In fact, the concept of structure-based lineages was established after the discovery of the similar topologies of the MCPs of bacteriophage PRD1 and human adenovirus [85]. The MCPs of these viruses contain two concatenated upright $\beta$-barrels (double jellyrolls; DJR), which are stacked in a specific manner [85]. In addition to the MCP fold, PRD1 and adenovirus share the same overall virion architecture [triangulation number $(T)=25$ icosahedral lattice] [90,91], vertex structure [31,92-94] and protein-primed replication mechanism. These similarities strongly suggest that PRD1 and adenovirus descended from a common ancestor. Later, similar DJR MCPs have been found in a number of viruses, including phage PM2 [32], archaeal Sulfolobus turreted icosahedral virus [95] (STIV) and Paramecium bulsaria Chlorella virus 1 (PBCV-1) infecting green algae [96]. Interestingly, the capsid of Thermus phage P23-77 is formed of two major protein types instead of one, both of which have a core fold of a single $\beta$-barrel, resembling the ones forming the DJR MCPs found in the PRD1-adenovirus lineage [97]. It has been suggested that P23-77 forms the earliest branch in the lineage. Similarly, phage SSIP-1 [10] and Thermus phage IN93 [98] display PRD1-adenovirus type architecture and encode two MCP types. P23-77, SSIP-1 and IN93 were all found from extreme environments. Most recently, the DJR fold was detected in the MCP of the phage FLiP, placing it into the PRD1-adenovirus lineage, even though its genome is ssDNA instead of dsDNA as in other members of the lineage [9]. Moreover, the DJR element 
has been identified in the genomes of a number of major bacterial and archaeal phyla, as well as in marine water column and sediment metagenomes, suggesting that the ecological and evolutionary importance of these viruses for microbial systems is greater than previously recognized [6,99]. The fact that the viral DJR MCP fold spans all three domains of life suggests that the lineage originated prior to the diversification of cellular life $[87,100]$. On the other hand, the similarities may also reflect the widespread horizontal transfer of MCP genes between viruses. Interestingly, the structure-based classification of the PRD1-adenovirus lineage is strongly supported by recently detected nucleotide and amino acid sequence similarities, further suggesting that the similarities between the lineage members result from common descent [101].

Also, cystoviruses share a common virion architecture and lifestyle with eukaryotic dsRNA viruses. These similarities reflect the common challenges faced by dsRNA viruses. Firstly, host cells lack the machinery to replicate dsRNA, and secondly, dsRNA molecules typically elicit strong cellular defense responses [89]. To overcome these challenges, the dsRNA genome is delivered into the host within a conserved core structure, the polymerase complex (PC), carrying all the enzymatic functions needed for viral replication and transcription. The phi6 PC consists of 120 copies of the MCP arranged in 60 asymmetric dimers $[T=1][35,102,103]$. This unique inner shell architecture has been identified in other cystoviruses [104,105], as well as in eukaryotic dsRNA viruses belonging to the families Reoviridae [106-109], Picobirnaviridae [110], Totiviridae [111-113], Partitiviridae [114,115], Megabirnaviridae [116] and Quadriviridae [117]. Also, the viral RNA-dependent RNA polymerases, the key enzymatic components of the dsRNA virus polymerase complexes, share a common structural fold [118].

Whereas the virion architecture is highly conserved, viral structures and functions related to host interaction are in a constant state of change, providing the means to adapt to new environments and hosts $[86,87,89]$. Corticovirus PM2 and the newly described corticovirus Cr39582 provide an example of such evolution with their syntenous genomes but non-homologous spike protein encoding genes [119]. Similarly, genome replication proteins may differ among closely related viruses, as in the case of aquatic PM2-like viruses [120]. Moreover, the additional virion layer present in some dsRNA viruses facilitates virus-host interaction and, therefore, displays more variability $[89,121]$. For instance, the sequences of the internal virion proteins and the enzymes of cystoviruses are highly conserved, but more variance is observed in proteins exposed on the virion surface (envelope proteins), resulting in different host specificities [75].

The early evolutionary history of some of the membrane-containing viruses might be shared with plasmids, offering a possible explanation for the origin of these viruses. This idea is supported by the recent finding of an Antarctic "infectious" plasmid vesicle that uses a virus-like transfer mechanism [122]. This system resembles notably pleomorphic prokaryotic viruses infecting bacterial and archaeal hosts [123-125].

\section{Applications of Membrane-Containing Phages}

Membrane-containing phages infect a wide range of bacterial species, many of which are pathogenic for plants, animals and humans. Thus, these viruses are potential biocontrol agents. For instance, cystoviruses have been suggested to provide means to treat bacterial infections afflicting both agriculturally important plants and humans [76]. Furthermore, conjugative plasmid-dependent phages, e.g., PRD1, provide a potential tool to restrict the horizontal spread of antibiotic resistance genes. These phages use receptors encoded by conjugative plasmids that belong to incompatibility groups IncP, IncN, or IncW and often carry antibiotic resistance genes [11], making antibiotic-resistant bacteria with conjugative plasmids targets for selective infection and removal [126,127].

Phage phi6 has provided several applications for the life sciences. The in vivo and in vitro dsRNA replication systems based on phi6 polymerase complex or RNA-dependent RNA polymerase enable the large-scale production of high-quality dsRNA molecules $[81,128]$ to be used in RNA interference applications against plant and human pathogens [81,129-133] or to induce innate immunity responses 
in human cell lines [134]. In addition, the phi6 major membrane protein has been used to improve the correct folding of heterologous membrane proteins in bacterial expression systems $[135,136]$ and to produce phi6-specific synthetic lipid scaffolds for enzymatic reactions in E. coli [137].

The discovery of new viruses from various environmental niches, from moderate to extreme, has also revealed new potential applications. Tectivirus-like phage Toil provides a novel environmentally friendly method to extract triacylglycerol from oleaginous bacterium Rhodococcus opacus for biodiesel production [70]. Extremophilic phages, exemplified by P23-77 from alkaline hot spring and SSIP-1 originating from extreme salinity, may also constitute an important source of novel enzymes for biotechnological applications $[10,97]$. In addition, the structure of P23-77 suggested mechanisms for stabilization and the assembly of protein-lipid systems at extremely high temperatures $[97,138]$. In general, an understanding of the mechanistic properties of the membrane-containing virus particles provides interesting new insights into the engineering of tough composite nanomaterials that are well suited to protect fragile cargos [37].

\section{Concluding Remarks}

Membranes provide ancillary means for viruses to overcome the surface barriers of the host bacteria [23]. The structures and specific functions of lipid bilayers differ greatly among phages, reflecting the enormous diversity among viruses and their remarkable ability to adapt to infect different host cells.

Recent evidence suggests that membrane-containing phages are more prevalent than has been previously thought, and they infect members of major bacterial taxa (such as Pseudomonas, Bacillus, Vibrio and Flavobacterium). Although the number of membrane-containing phage isolates is still rather limited, the genetic, structural and functional data that originate from these biological entities have been instrumental in the development of virus research, providing new insights into, e.g., virus assembly, virion structure, and infection mechanisms as well as bringing up the concept of virus lineages to group viruses based on their conserved structural elements. It is likely that future research will provide additional interesting molecular insights into the infection processes of different membrane-containing phages. Such information forms the foundation for a deeper understanding of this fascinating group of viruses, paving the way for new innovations and applications.

Author Contributions: Writing—original draft preparation, S.M.; writing—review and editing, L.-R.S., H.M.O. and M.M.P.; visualization, S.M.

Funding: This work was funded by the Finnish Centre of Excellence Program of the Academy of Finland; the CoE in Biological Interactions 2012-2017 (\#252411), Academy of Finland grants \#266879 and \#314939 (L.-R.S.), and the Jane and Aatos Erkko Foundation and the Sigrid Juselius Foundation (M.M.P.). H.M.O. was supported by funding for Instruct-FI (Instruct-HiLIFE and Biocenter Finland).

Acknowledgments: We thank Samuel L. Díaz-Muñoz and his research group (University of California, Davis) for invaluable insights and support.

Conflicts of Interest: The authors declare no conflict of interest. The funders had no role in the design of the study; in the collection, analyses, or interpretation of data; in the writing of the manuscript, or in the decision to publish the results.

\section{References}

1. Roine, E.; Bamford, D.H. Lipids of archaeal viruses. Archaea 2012, 2012, 384919. [CrossRef] [PubMed]

2. Ackermann, H.W.; Prangishvili, D. Prokaryote viruses studied by electron microscopy. Arch. Virol. 2012, 157, 1843-1849. [CrossRef] [PubMed]

3. Atanasova, N.S.; Senčilo, A.; Pietilä, M.K.; Roine, E.; Oksanen, H.M.; Bamford, D.H. Comparison of lipid-containing bacterial and archaeal viruses. Adv. Virus Res. 2015, 92, 1-61. [PubMed]

4. Silander, O.K.; Weinreich, D.M.; Wright, K.M.; O'Keefe, K.J.; Rang, C.U.; Turner, P.E.; Chao, L. Widespread genetic exchange among terrestrial bacteriophages. Proc. Natl. Acad. Sci. USA 2005, 102, 19009-19014. [CrossRef] [PubMed] 
5. O'Keefe, K.J.; Silander, O.K.; McCreery, H.; Weinreich, D.M.; Wright, K.M.; Chao, L.; Edwards, S.V.; Remold, S.K.; Turner, P.E. Geographic differences in sexual reassortment in RNA phage. Evolution 2010, 64, 3010-3023. [CrossRef] [PubMed]

6. Kaufmann, K.; Hussain, F.; Yang, J.; Arevalo, P.; Brown, J.; Chang, W.; Van Insberghe, D.; Elsherbini, J.; Sharma, R.; Cutler, M.; et al. A major lineage of non-tailed dsDNA viruses as unrecognized killers of marine bacteria. Nature 2018, 554, 261-295. [CrossRef] [PubMed]

7. Brüssow, H.; Hendrix, R.W. Phage genomics: Small is beautiful. Cell 2002, 108, 13-16. [CrossRef]

8. Espejo, R.T.; Canelo, E.S. Properties and characterization of the host bacterium of bacteriophage PM2. J. Bacteriol. 1968, 95, 1887-1891.

9. Laanto, E.; Mäntynen, S.; De Colibus, L.; Marjakangas, J.; Gillum, A.; Stuart, D.I.; Ravantti, J.J.; Huiskonen, J.T.; Sundberg, L.R. Virus found in a boreal lake links ssDNA and dsDNA viruses. Proc. Natl. Acad. Sci. USA 2017, 114, 8378-8383. [CrossRef]

10. Aalto, A.P.; Bitto, D.; Ravantti, J.J.; Bamford, D.H.; Huiskonen, J.T.; Oksanen, H.M. Snapshot of virus evolution in hypersaline environments from the characterization of a membrane-containing Salisaeta icosahedral phage 1. Proc. Natl. Acad. Sci. USA 2012, 109, 7079-7084. [CrossRef]

11. Olsen, R.H.; Siak, J.S.; Gray, R.H. Characteristics of PRD1, a plasmid-dependent broad host range DNA bacteriophage. J. Virol. 1974, 14, 689-699. [PubMed]

12. Vidaver, A.K.; Koski, R.K.; Van Etten, J.L. Bacteriophage phi6: A lipid-containing virus of Pseudomonas phaseolicola. J. Virol. 1973, 11, 799-805. [PubMed]

13. Wichels, A.; Biel, S.S.; Gelderblom, H.R.; Brinkhoff, T.; Muyzer, G.; Schütt, C. Bacteriophage diversity in the North Sea. Appl. Environ. Microbiol. 1998, 64, 4128-4133. [PubMed]

14. Adams, M.H. Bacteriophages; Interscience Publishers Inc.: New York, NY, USA, 1959.

15. Castro-Mejía, J.L.; Muhammed, M.K.; Kot, W.; Neve, H.; Franz, C.M.; Hansen, L.H.; Vogensen, F.K.; Nielsen, D.S. Optimizing protocols for extraction of bacteriophages prior to metagenomic analyses of phage communities in the human gut. Microbiome 2015, 3, 64. [CrossRef] [PubMed]

16. Thurber, R.V.; Haynes, M.; Breitbart, M.; Wegley, L.; Rohwer, F. Laboratory procedures to generate viral metagenomes. Nat. Protoc. 2009, 4, 470-483. [CrossRef] [PubMed]

17. Cronan, J.E. Bacterial membrane lipids: Where do we stand? Annu. Rev. Microbiol. 2003, 57, $203-224$. [CrossRef] [PubMed]

18. Davis, T.N.; Müller, E.D.; Cronan, J.E., Jr. The virion of the lipid-containing bacteriophage PR4. Virology 1982, 120, 287-306. [CrossRef]

19. Greenberg, N.; Rottem, S. Composition and molecular organization of lipids and proteins in the envelope of mycoplasmavirus MVL2. J. Virol. 1979, 32, 717-726.

20. Laurinavičius, S.; Bamford, D.H.; Somerharju, P. Transbilayer distribution of phospholipids in bacteriophage membranes. Biochim. Biophys. Acta 2007, 1768, 2568-2577. [CrossRef]

21. Laurinavičius, S.; Käkelä, R.; Somerharju, P.; Bamford, D.H. Phospholipid molecular species profiles of tectiviruses infecting Gram-negative and Gram-positive hosts. Virology 2004, 322, 328-336. [CrossRef]

22. Cockburn, J.J.; Abrescia, N.G.; Grimes, J.M.; Sutton, G.C.; Diprose, J.M.; Benevides, J.M.; Thomas, G.J., Jr.; Bamford, J.K.; Bamford, D.H.; Stuart, D.I. Membrane structure and interactions with protein and DNA in bacteriophage PRD1. Nature 2004, 432, 122-125. [CrossRef] [PubMed]

23. Poranen, M.M.; Bamford, D.H.; Oksanen, H.M. Membrane-containing bacteriophages. In Encyclopedia of Life Sciences; John Wiley \& Sons: Chichester, UK, 2015.

24. Dyall-Smith, M.L. Genus Salterprovirus. In Virus Taxonomy, Ninth Report of the International Committee on Taxonomy of Viruses; King, A.M.Q., Adams, M.J., Carstens, E.B., Lefkowitz, E.J., Eds.; Elsevier Academic Press: San Diego, CA, USA, 2011; pp. 183-186.

25. London, E.; Feigenson, G.W. Phosphorus NMR analysis of phospholipids in detergents. J. Lipid Res. 1979, 20, 408-412. [PubMed]

26. Corcelli, A.; Lobasso, S. Characterization of lipids of halophilic Archaea. In Methods in Microbiology_Extremophiles; Rainey, F.A., Oren, A., Eds.; Elsevier: Amsterdam, The Netherlands, 2006; pp. 585-613.

27. Oksanen, H.M.; Domanska, A.; Bamford, D.H. Monolithic ion exchange chromatographic methods for virus purification. Virology 2012, 434, 271-277. [CrossRef] [PubMed] 
28. Eskelin, K.; Lampi, M.; Meier, F.; Moldenhauer, E.; Bamford, D.H.; Oksanen, H.M. Asymmetric flow field flow fractionation methods for virus purification. J. Chromatogr. A 2016, 1469, 108-119. [CrossRef] [PubMed]

29. Murphy, R.C.; Gaskell, S.J. New applications of mass spectrometry in lipid analysis. J. Biol. Chem. 2011, 286, 25427-25433. [CrossRef] [PubMed]

30. Vitale, R.; Roine, E.; Bamford, D.H.; Corcelli, A. Lipid fingerprints of intact viruses by MALDI-TOF/mass spectrometry. Biochim. Biophys. Acta 2013, 1831, 872-879. [CrossRef] [PubMed]

31. Abrescia, N.G.; Cockburn, J.J.; Grimes, J.M.; Sutton, G.C.; Diprose, J.M.; Butcher, S.J.; Fuller, S.D.; San Martin, C.; Burnett, R.M.; Stuart, D.I.; et al. Insights into assembly from structural analysis of bacteriophage PRD1. Nature 2004, 432, 68-74. [CrossRef]

32. Abrescia, N.G.; Grimes, J.M.; Kivelä, H.M.; Assenberg, R.; Sutton, G.C.; Butcher, S.J.; Bamford, J.K.; Bamford, D.H.; Stuart, D.I. Insights into virus evolution and membrane biogenesis from the structure of the marine lipid-containing bacteriophage PM2. Mol. Cell 2008, 31, 749-761. [CrossRef]

33. Hong, C.; Oksanen, H.M.; Liu, X.; Jakana, J.; Bamford, D.H.; Chiu, W. A structural model of the genome packaging process in a membrane-containing double stranded DNA virus. PLoS Biol. 2014, 12, e1002024. [CrossRef]

34. Peralta, B.; Gil-Carton, D.; Castaño-Díez, D.; Bertin, A.; Boulogne, C.; Oksanen, H.M.; Bamford, D.H.; Abrescia, N.G. Mechanism of membranous tunnelling nanotube formation in viral genome delivery. PLoS Biol. 2013, 11, e1001667. [CrossRef]

35. Ilca, S.L.; Kotecha, A.; Sun, X.; Poranen, M.M.; Stuart, D.I.; Huiskonen, J.T. Localized reconstruction of subunits from electron cryomicroscopy images of macromolecular complexes. Nat. Commun. 2015, 6, 8843. [CrossRef] [PubMed]

36. Ilca, S.L.; Sun, X.; El Omari, K.; Kotecha, A.; de Haas, F.; diMaio, F.; Grimes, J.M.; Stuart, D.I.; Poranen, M.M.; Huiskonen, J.T. Multiple liquid crystalline geometries of highly compacted nucleic acid in a dsRNA virus. 2019. revision under review.

37. Azinas, S.; Bano, F.; Torca, I.; Bamford, D.H.; Schwartz, G.A.; Esnaola, J.; Oksanen, H.M.; Richter, R.P.; Abrescia, N.G. Membrane-containing virus particles exhibit the mechanics of a composite material for genome protection. Nanoscale 2018, 10, 7769-7779. [CrossRef]

38. Harrison, S.C. Viral membrane fusion. Virology 2015, 479-480, 498-507. [CrossRef] [PubMed]

39. Bamford, D.H.; Romantschuk, M.; Somerharju, P.J. Membrane fusion in prokaryotes: Bacteriophage $\phi 6$ membrane fuses with the Pseudomonas syringae outer membrane. EMBO J. 1987, 6, 1467-1473. [CrossRef] [PubMed]

40. Poranen, M.M.; Bamford, D.H. Entry of a segmented dsRNA virus into the bacterial cell. In Segmented Double-Stranded RNA Viruses; Patton, J.T., Ed.; Caister Academic Press: Norfolk, UK, 2008; pp. 215-226.

41. Romantschuk, M.; Olkkonen, V.M.; Bamford, D.H. The nucleocapsid of bacteriophage $\phi 6$ penetrates the host cytoplasmic membrane. EMBO J. 1988, 7, 1821-1829. [CrossRef]

42. Poranen, M.M.; Daugelavicius, R.; Ojala, P.M.; Hess, M.W.; Bamford, D.H. A novel virus-host cell membrane interaction. Membrane voltage-dependent endocytic-like entry of bacteriophage $\phi 6$ nucleocapsid. J. Cell Biol. 1999, 147, 671-682. [CrossRef]

43. Cvirkaitè-Krupovič, V.; Poranen, M.M.; Bamford, D.H. Phospholipids act as secondary receptor during the entry of the enveloped, double-stranded RNA bacteriophage phi6. J. Gen. Virol. 2010, 91, 2116-2120. [CrossRef]

44. Putzrath, R.M.; Maniloff, J. Growth of an enveloped mycoplasmavirus and establishment of a carrier state. J. Virol. 1977, 22, 308-314.

45. Gaidelytè, A.; Cvirkaitè-Krupovič, V.; Daugelavicius, R.; Bamford, J.K.; Bamford, D.H. The entry mechanism of membrane-containing phage Bam35 infecting Bacillus thuringiensis. J. Bacteriol. 2006, 188, 5925-5934. [CrossRef]

46. Santos-Pérez, I.; Oksanen, H.M.; Bamford, D.H.; Goñi, F.M.; Reguera, D.; Abrescia, N.G.A. Membrane-assisted viral DNA ejection. Biochim. Biophys. Acta 2017, 1861, 664-672. [CrossRef] [PubMed]

47. Bamford, D.; Mindich, L. Structure of the lipid-containing bacteriophage PRD1: Disruption of wild-type and nonsense mutant phage particles with guanidine hydrochloride. J. Virol. 1982, 44, 1031-1038. [PubMed]

48. Grahn, A.M.; Daugelavicius, R.; Bamford, D.H. Sequential model of phage PRD1 DNA delivery: Active involvement of the viral membrane. Mol. Microbiol. 2002, 46, 1199-1209. [CrossRef] [PubMed] 
49. Sun, L.; Young, L.N.; Zhang, X.; Boudko, S.P.; Fokine, A.; Zbornik, E.; Roznowski, A.P.; Molineux, I.J.; Rossmann, M.G.; Fane, B.A. Icosahedral bacteriophage $\phi X 174$ forms a tail for DNA transport during infection. Nature 2014, 505, 432-435. [CrossRef] [PubMed]

50. Molineux, I.J.; Panja, D. Popping the cork: Mechanisms of phage genome ejection. Nat. Rev. Microbiol. 2013, 11, 194-204. [CrossRef] [PubMed]

51. Kivelä, H.M.; Daugelavicius, R.; Hankkio, R.H.; Bamford, J.K.; Bamford, D.H. Penetration of membrane-containing double-stranded-DNA bacteriophage PM2 into Pseudoalteromonas hosts. J. Bacteriol. 2004, 186, 5342-5354. [CrossRef]

52. Kivelä, H.M.; Madonna, S.; Krupovič, M.; Tutino, M.L.; Bamford, J.K. Genetics for Pseudoalteromonas provides tools to manipulate marine bacterial virus PM2. J. Bacteriol. 2008, 190, 1298-1307. [CrossRef] [PubMed]

53. Cvirkaite-Krupovič, V.; Krupovič, M.; Daugelavicius, R.; Bamford, D.H. Calcium ion-dependent entry of the membrane-containing bacteriophage PM2 into its Pseudoalteromonas host. Virology 2010, 405, 120-128. [CrossRef]

54. Welsch, S.; Müller, B.; Kräusslich, H.G. More than one door - budding of enveloped viruses through cellular membranes. FEBS Lett. 2007, 581, 2089-2097. [CrossRef]

55. Johnson, M.D.; Mindich, L. Plasmid-directed assembly of the lipid-containing membrane of bacteriophage ф6. J. Bacteriol. 1994, 176, 4124-4132. [CrossRef]

56. Sarin, L.P.; Hirvonen, J.J.; Laurinmäki, P.; Butcher, S.J.; Bamford, D.H.; Poranen, M.M. Bacteriophage $\phi 6$ nucleocapsid surface protein 8 interacts with virus-specific membrane vesicles containing major envelope protein 9. J. Virol. 2012, 86, 5376-5379. [CrossRef] [PubMed]

57. Bamford, D.H.; Palva, E.T.; Lounatmaa, K. Ultrastructure and life cycle of the lipid-containing bacteriophage ф6. J. Gen. Virol. 1976, 32, 249-259. [CrossRef] [PubMed]

58. Mindich, L.; Bamford, D.; McGraw, T.; Mackenzie, G. Assembly of bacteriophage PRD1: Particle formation with wild-type and mutant viruses. J. Virol. 1982, 44, 1021-1030. [PubMed]

59. Rydman, P.S.; Bamford, J.K.; Bamford, D.H. A minor capsid protein P30 is essential for bacteriophage PRD1 capsid assembly. J. Mol. Biol. 2001, 313, 785-795. [CrossRef] [PubMed]

60. Gowen, B.; Bamford, J.K.; Bamford, D.H.; Fuller, S.D. The tailless icosahedral membrane virus PRD1 localizes the proteins involved in genome packaging and injection at a unique vertex. J. Virol. 2003, 77, 7863-7871. [CrossRef] [PubMed]

61. Strömsten, N.J.; Bamford, D.H.; Bamford, J.K. In vitro DNA packaging of PRD1: A common mechanism for internal-membrane viruses. J. Mol. Biol. 2005, 348, 617-629. [CrossRef]

62. Karhu, N.J.; Ziedaite, G.; Bamford, D.H.; Bamford, J.K. Efficient DNA packaging of bacteriophage PRD1 requires the unique vertex protein P6. J. Virol. 2007, 81, 2970-2979. [CrossRef]

63. Ziedaite, G.; Kivelä, H.M.; Bamford, J.K.; Bamford, D.H. Purified membrane-containing procapsids of bacteriophage PRD1 package the viral genome. J. Mol. Biol. 2009, 386, 637-647. [CrossRef]

64. Rydman, P.S.; Bamford, D.H. Identification and mutational analysis of bacteriophage PRD1 holin protein P35. J. Bacteriol. 2003, 185, 3795-3803. [CrossRef]

65. Mindich, L.; Bamford, D.; Goldthwaite, C.; Laverty, M.; Mackenzie, G. Isolation of nonsense mutants of lipid-containing bacteriophage PRD1. J. Virol. 1982, 44, 1013-1020.

66. Caldentey, J.; Hänninen, A.L.; Bamford, D.H. Gene XV of bacteriophage PRD1 encodes a lytic enzyme with muramidase activity. Eur. J. Biochem. 1994, 225, 341-346. [CrossRef] [PubMed]

67. Ziedaite, G.; Daugelavicius, R.; Bamford, J.K.; Bamford, D.H. The holin protein of bacteriophage PRD1 forms a pore for small-molecule and endolysin translocation. J. Bacteriol. 2005, 187, 5397-5405. [CrossRef] [PubMed]

68. Krupovič, M.; Cvirkaitè-Krupovič, V.; Bamford, D.H. Identification and functional analysis of the Rz/Rz1-like accessory lysis genes in the membrane-containing bacteriophage PRD1. Mol. Microbiol. 2008, 68, 492-503. [CrossRef] [PubMed]

69. Krupovič, M.; Daugelavicius, R.; Bamford, D.H. A novel lysis system in PM2, a lipid-containing marine double-stranded DNA bacteriophage. Mol. Microbiol. 2007, 64, 1635-1648. [CrossRef] [PubMed]

70. Gill, J.J.; Wang, B.; Sestak, E.; Young, R.; Chu, K.H. Characterization of a novel tectivirus phage Toil and its potential as an agent for biolipid extraction. Sci. Rep. 2018, 8, 1062. [CrossRef] [PubMed] 
71. Philippe, C.; Krupovič, M.; Jaomanjaka, F.; Claisse, O.; Petrel, M.; le Marrec, C. Bacteriophage GC1, a novel tectivirus infecting Gluconobacter cerinus, an acetic acid bacterium associated with wine-making. Viruses 2018, 10, 39. [CrossRef]

72. Jalasvuori, M.; Palmu, S.; Gillis, A.; Kokko, H.; Mahillon, J.; Bamford, J.K.; Fornelos, N. Identification of five novel tectiviruses in Bacillus strains: Analysis of a highly variable region generating genetic diversity. Res. Microbiol. 2013, 164, 118-126. [CrossRef]

73. Gillis, A.; Mahillon, J. Prevalence, genetic diversity, and host range of tectiviruses among members of the Bacillus cereus group. Appl. Environ. Microbiol. 2014, 80, 4138-4152. [CrossRef]

74. Mindich, L.; Qiao, X.; Qiao, J.; Onodera, S.; Romantschuk, M.; Hoogstraten, D. Isolation of additional bacteriophages with genomes of segmented double-stranded RNA. J. Bacteriol. 1999, 181, 4505-4508.

75. Mäntynen, S.; Laanto, E.; Kohvakka, A.; Poranen, M.M.; Bamford, J.K.; Ravantti, J.J. New enveloped dsRNA phage from freshwater habitat. J. Gen. Virol. 2015, 96, 1180-1189. [CrossRef]

76. Yang, Y.; Lu, S.; Shen, W.; Zhao, X.; Shen, M.; Tan, Y.; Li, G.; Li, M.; Wang, J.; Hu, F.; et al. Characterization of the first double-stranded RNA bacteriophage infecting Pseudomonas aeruginosa. Sci. Rep. 2016, 6, 38795. [CrossRef] [PubMed]

77. Mäntynen, S.; Sundberg, L.R.; Poranen, M.M. Recognition of six additional cystoviruses: Pseudomonas virus phi6 is no longer the sole species of the family Cystoviridae. Arch. Virol. 2018, 163, 1117-1124. [CrossRef] [PubMed]

78. Zhang, Y.M.; Rock, C.O. Membrane lipid homeostasis in bacteria. Nat. Rev. Microbiol. 2008, 6, $222-233$. [CrossRef] [PubMed]

79. Gillis, A.; Mahillon, J. Influence of lysogeny of tectiviruses GIL01 and GIL16 on Bacillus thuringiensis growth, biofilm formation, and swarming motility. Appl. Environ. Microbiol. 2014, 80, 7620-7630. [CrossRef] [PubMed]

80. Romantschuk, M.; Bamford, D.H. ф6-resistant phage-producing mutants of Pseudomonas phaseolicola. J. Gen. Virol. 1981, 56, 287-295. [CrossRef] [PubMed]

81. Niehl, A.; Soininen, M.; Poranen, M.M.; Heinlein, M. Synthetic biology approach for plant protection using dsRNA. Plant. Biotechnol. J. 2018, 16, 1679-1687. [CrossRef] [PubMed]

82. Uchiyama, J.; Takeuchi, H.; Kato, S.; Gamoh, K.; Takemura-Uchiyama, I.; Ujihara, T.; Daibata, M.; Matsuzaki, S. Characterization of Helicobacter pylori bacteriophage KHP30. Appl. Environ. Microbiol. 2013, 79, 3176-3184. [CrossRef]

83. Ripp, S.; Miller, R.V. The role of pseudolysogeny in bacteriophage-host interactions in a natural freshwater environment. Microbiology 1997, 143, 2065-2070. [CrossRef]

84. Doron, S.; Melamed, S.; Ofir, G.; Leavitt, A.; Lopatina, A.; Keren, M.; Amitai, G.; Sorek, R. Systematic discovery of antiphage defense systems in the microbial pangenome. Science 2018, 359, eaar4120. [CrossRef]

85. Benson, S.D.; Bamford, J.K.; Bamford, D.H.; Burnett, R.M. Viral evolution revealed by bacteriophage PRD1 and human adenovirus coat protein structures. Cell 1999, 98, 825-833. [CrossRef]

86. Bamford, D.H.; Grimes, J.M.; Stuart, D.I. What does structure tell us about virus evolution? Curr. Opin. Struct. Biol. 2005, 15, 655-663. [CrossRef]

87. Bamford, D.H. Do viruses form lineages across different domains of life? Res. Microbiol. 2003, 154, $231-236$. [CrossRef]

88. Abrescia, N.G.; Bamford, D.H.; Grimes, J.M.; Stuart, D.I. Structure unifies the viral universe. Annu. Rev. Biochem. 2012, 81, 795-822. [CrossRef] [PubMed]

89. Bamford, D.H.; Burnett, R.M.; Stuart, D.I. Evolution of viral structure. Theor. Popul. Biol. 2002, 61, 461-470. [CrossRef] [PubMed]

90. Stewart, P.L.; Burnett, R.M.; Cyrklaff, M.; Fuller, S.D. Image reconstruction reveals the complex molecular organization of adenovirus. Cell 1991, 67, 145-154. [CrossRef]

91. Butcher, S.J.; Bamford, D.H.; Fuller, S.D. DNA packaging orders the membrane of bacteriophage PRD1. EMBO J. 1995, 14, 6078-6086. [CrossRef] [PubMed]

92. Van Raaij, M.J.; Mitraki, A.; Lavigne, G.; Cusack, S. A triple $\beta$-spiral in the adenovirus fibre shaft reveals a new structural motif for a fibrous protein. Nature 1999, 401, 935-938. [CrossRef] [PubMed]

93. Zubieta, C.; Schoehn, G.; Chroboczek, J.; Cusack, S. The structure of the human adenovirus 2 penton. Mol. Cell 2005, 17, 121-135. [CrossRef] [PubMed] 
94. Merckel, M.C.; Huiskonen, J.T.; Bamford, D.H.; Goldman, A.; Tuma, R. The structure of the bacteriophage PRD1 spike sheds light on the evolution of viral capsid architecture. Mol. Cell 2005, 18, 161-170. [CrossRef] [PubMed]

95. Khayat, R.; Tang, L.; Larson, E.T.; Lawrence, C.M.; Young, M.; Johnson, J.E. Structure of an archaeal virus capsid protein reveals a common ancestry to eukaryotic and bacterial viruses. Proc. Natl. Acad. Sci. USA 2005, 102, 18944-18949. [CrossRef]

96. Nandhagopal, N.; Simpson, A.A.; Gurnon, J.R.; Yan, X.; Baker, T.S.; Graves, M.V.; Van Etten, J.L.; Rossmann, M.G. The structure and evolution of the major capsid protein of a large, lipid-containing DNA virus. Proc. Natl. Acad. Sci. USA 2002, 99, 14758-14763. [CrossRef] [PubMed]

97. Rissanen, I.; Grimes, J.M.; Pawlowski, A.; Mäntynen, S.; Harlos, K.; Bamford, J.K.; Stuart, D.I. Bacteriophage P23-77 capsid protein structures reveal the archetype of an ancient branch from a major virus lineage. Structure 2013, 21, 718-726. [CrossRef] [PubMed]

98. Matsushita, I.; Yanase, H. The genomic structure of Thermus bacteriophage $\varphi$ IN93. J. Biochem. 2009, 146, 775-785. [CrossRef] [PubMed]

99. Yutin, N.; Bäckström, D.; Ettema, T.J.G.; Krupovic, M.; Koonin, E.V. Vast diversity of prokaryotic virus genomes encoding double jelly-roll major capsid proteins uncovered by genomic and metagenomic sequence analysis. Virol. J. 2018, 15, 67. [CrossRef] [PubMed]

100. Benson, S.D.; Bamford, J.K.; Bamford, D.H.; Burnett, R.M. Does common architecture reveal a viral lineage spanning all three domains of life? Mol. Cell 2004, 16, 673-685. [CrossRef] [PubMed]

101. Sinclair, R.M.; Ravantti, J.J.; Bamford, D.H. Nucleic and amino acid sequences support structure-based viral classification. J. Virol. 2017, 91, e02275-16. [CrossRef] [PubMed]

102. Huiskonen, J.T.; de Haas, F.; Bubeck, D.; Bamford, D.H.; Fuller, S.D.; Butcher, S.J. Structure of the bacteriophage $\phi 6$ nucleocapsid suggests a mechanism for sequential RNA packaging. Structure 2006, 14, 1039-1048. [CrossRef]

103. Sun, Z.; El Omari, K.; Sun, X.; Ilca, S.L.; Kotecha, A.; Stuart, D.I.; Poranen, M.M.; Huiskonen, J.T. Double-stranded RNA virus outer shell assembly by bona fide domain-swapping. Nat. Commun. 2017, 8, 14814. [CrossRef]

104. Nemecek, D.; Boura, E.; Wu, W.; Cheng, N.; Plevka, P.; Qiao, J.; Mindich, L.; Heymann, J.B.; Hurley, J.H.; Steven, A.C. Subunit folds and maturation pathway of a dsRNA virus capsid. Structure 2013, 21, 1374-1383. [CrossRef]

105. El Omari, K.; Sutton, G.; Ravantti, J.J.; Zhang, H.; Walter, T.S.; Grimes, J.M.; Bamford, D.H.; Stuart, D.I.; Mancini, E.J. Plate tectonics of virus shell assembly and reorganization in phage $\phi 8$, a distant relative of mammalian reoviruses. Structure 2013, 21, 1384-1395. [CrossRef]

106. Grimes, J.M.; Burroughs, J.N.; Gouet, P.; Diprose, J.M.; Malby, R.; Zientara, S.; Mertens, P.P.; Stuart, D.I. The atomic structure of the bluetongue virus core. Nature 1998, 395, 470-478. [CrossRef] [PubMed]

107. Reinisch, K.M.; Nibert, M.L.; Harrison, S.C. Structure of the reovirus core at $3.6 \AA$ resolution. Nature 2000, 404, 960-967. [CrossRef] [PubMed]

108. Yu, X.; Jin, L.; Zhou, Z.H. 3.88 A structure of cytoplasmic polyhedrosis virus by cryo-electron microscopy. Nature 2008, 453, 415-419. [CrossRef] [PubMed]

109. Settembre, E.C.; Chen, J.Z.; Dormitzer, P.R.; Grigorieff, N.; Harrison, S.C. Atomic model of an infectious rotavirus particle. EMBO J. 2011, 30, 408-416. [CrossRef] [PubMed]

110. Duquerroy, S.; Da Costa, B.; Henry, C.; Vigouroux, A.; Libersou, S.; Lepault, J.; Navaza, J.; Delmas, B.; Rey, F.A. The picobirnavirus crystal structure provides functional insights into virion assembly and cell entry. EMBO J. 2009, 28, 1655-1665. [CrossRef] [PubMed]

111. Naitow, H.; Tang, J.; Canady, M.; Wickner, R.B.; Johnson, J.E. L-A virus at $3.4 \AA$ resolution reveals particle architecture and mRNA decapping mechanism. Nat. Struct. Biol. 2002, 9, 725-728. [CrossRef] [PubMed]

112. Parent, K.N.; Takagi, Y.; Cardone, G.; Olson, N.H.; Ericsson, M.; Yang, M.; Lee, Y.; Asara, J.M.; Fichorova, R.N.; Baker, T.S.; et al. Structure of a protozoan virus from the human genitourinary parasite Trichomonas vaginalis. mBio 2013, 4, e00056-13. [CrossRef]

113. Janssen, M.E.; Takagi, Y.; Parent, K.N.; Cardone, G.; Nibert, M.L.; Baker, T.S. Three-dimensional structure of a protozoal double-stranded RNA virus that infects the enteric pathogen Giardia lamblia. J. Virol. 2015, 89, 1182-1194. [CrossRef] 
114. Pan, J.; Dong, L.; Lin, L.; Ochoa, W.F.; Sinkovits, R.S.; Havens, W.M.; Nibert, M.L.; Baker, T.S.; Ghabrial, S.A.; Tao, Y.J. Atomic structure reveals the unique capsid organization of a dsRNA virus. Proc. Natl. Acad. Sci. USA 2009, 106, 4225-4230. [CrossRef]

115. Tang, J.; Ochoa, W.F.; Li, H.; Havens, W.M.; Nibert, M.L.; Ghabrial, S.A.; Baker, T.S. Structure of Fusarium poae virus 1 shows conserved and variable elements of partitivirus capsids and evolutionary relationships to picobirnavirus. J. Struct. Biol. 2010, 172, 363-371. [CrossRef]

116. Miyazaki, N.; Salaipeth, L.; Kanematsu, S.; Iwasaki, K.; Suzuki, N. Megabirnavirus structure reveals a putative 120-subunit capsid formed by asymmetrical dimers with distinctive large protrusions. J. Gen. Virol. 2015, 96, 2435-2441. [CrossRef] [PubMed]

117. Luque, D.; Mata, C.P.; González-Camacho, F.; González, J.M.; Gómez-Blanco, J.; Alfonso, C.; Rivas, G.; Havens, W.M.; Kanematsu, S.; Suzuki, N.; et al. Heterodimers as the structural unit of the T=1 capsid of the fungal double-stranded RNA Rosellinia necatrix quadrivirus 1. J. Virol. 2016, 90, 11220-11230. [CrossRef] [PubMed]

118. Mönttinen, H.A.; Ravantti, J.J.; Stuart, D.I.; Poranen, M.M. Automated structural comparisons clarify the phylogeny of the right-hand-shaped polymerases. Mol. Biol. Evol. 2014, 31, 2741-2752. [CrossRef] [PubMed]

119. Leigh, B.A.; Breitbart, M.; Oksanen, H.M.; Bamford, D.H.; Dishaw, L.J. Genome sequence of PM2-like phage Cr39582, induced from a Pseudoalteromonas sp. isolated from the gut of Ciona robusta. Genome Announc. 2018, 6, e00368-18. [CrossRef] [PubMed]

120. Krupovič, M.; Bamford, D.H. Putative prophages related to lytic tailless marine dsDNA phage PM2 are widespread in the genomes of aquatic bacteria. BMC Genomics 2007, 8, 236. [CrossRef] [PubMed]

121. Poranen, M.M.; Bamford, D.H. Assembly of large icosahedral double-stranded RNA viruses. Adv. Exp. Med. Biol. 2012, 726, 379-402.

122. Erdmann, S.; Tschitschko, B.; Zhong, L.; Raftery, M.J.; Cavicchioli, R. A plasmid from an Antarctic haloarchaeon uses specialized membrane vesicles to disseminate and infect plasmid-free cells. Nat. Microbiol. 2017, 2, 1446-1455. [CrossRef]

123. Dybvig, K.; Nowak, J.A.; Sladek, T.L.; Maniloff, J. Identification of an enveloped phage, mycoplasma virus L172, that contains a 14-kilobase single-stranded DNA genome. J. Virol. 1985, 53, 384-390.

124. Forterre, P.; Da Cunha, V.; Catchpole, R. Plasmid vesicles mimicking virions. Nat. Microbiol. 2017, 2, 1340-1341. [CrossRef]

125. Pietilä, M.K.; Atanasova, N.S.; Manole, V.; Liljeroos, L.; Butcher, S.J.; Oksanen, H.M.; Bamford, D.H. Virion architecture unifies globally distributed pleolipoviruses infecting halophilic archaea. J. Virol. 2012, 86, 5067-5079. [CrossRef]

126. Ojala, V.; Laitalainen, J.; Jalasvuori, M. Fight evolution with evolution: Plasmid-dependent phages with a wide host range prevent the spread of antibiotic resistance. Evol. Appl. 2013, 6, 925-932. [CrossRef]

127. Ojala, V.; Mattila, S.; Hoikkala, V.; Bamford, J.K.; Hiltunen, T.; Jalasvuori, M. Scoping the effectiveness and evolutionary obstacles in using plasmid-dependent phages to fight antibiotic resistance. Future Microbiol. 2016, 11, 999-1009. [CrossRef] [PubMed]

128. Aalto, A.P.; Sarin, L.P.; van Dijk, A.A.; Saarma, M.; Poranen, M.M.; Arumäe, U.; Bamford, D.H. Large-scale production of dsRNA and siRNA pools for RNA interference utilizing bacteriophage $\phi 6$ RNA-dependent RNA polymerase. RNA 2007, 13, 422-429. [CrossRef]

129. Romanovskaya, A.; Paavilainen, H.; Nygårdas, M.; Bamford, D.H.; Hukkanen, V.; Poranen, M.M. Enzymatically produced pools of canonical and Dicer-substrate siRNA molecules display comparable gene silencing and antiviral activities against herpes simplex virus. PLoS ONE 2012, 7, e51019. [CrossRef] [PubMed]

130. Voloudakis, A.E.; Holeva, M.C.; Sarin, L.P.; Bamford, D.H.; Vargas, M.; Poranen, M.M.; Tenllado, F. Efficient double-stranded RNA production methods for utilization in plant virus control. Methods Mol. Biol. 2015, 1236, 255-274. [PubMed]

131. Paavilainen, H.; Lehtinen, J.; Romanovskaya, A.; Nygårdas, M.; Bamford, D.H.; Poranen, M.M.; Hukkanen, V. Inhibition of clinical pathogenic herpes simplex virus 1 strains with enzymatically created siRNA pools. J. Med. Virol. 2016, 88, 2196-2205. [CrossRef] [PubMed]

132. Paavilainen, H.; Romanovskaya, A.; Nygårdas, M.; Bamford, D.H.; Poranen, M.M.; Hukkanen, V. Innate responses to small interfering RNA pools inhibiting herpes simplex virus infection in astrocytoid and epithelial cells. Innate Immun. 2015, 21, 349-357. [CrossRef] 
133. Paavilainen, H.; Lehtinen, J.; Romanovskaya, A.; Nygårdas, M.; Bamford, D.H.; Poranen, M.M.; Hukkanen, V. Topical treatment of herpes simplex virus infection with enzymatically created siRNA swarm. Antivir. Ther. 2017, 22, 631-637. [CrossRef] [PubMed]

134. Jiang, M.; Österlund, P.; Sarin, L.P.; Poranen, M.M.; Bamford, D.H.; Guo, D.; Julkunen, I. Innate immune responses in human monocyte-derived dendritic cells are highly dependent on the size and the $5^{\prime}$ phosphorylation of RNA molecules. J. Immunol. 2011, 187, 1713-1721. [CrossRef] [PubMed]

135. Na, J.H.; Shin, J.; Jung, Y.; Lim, D.; Shin, Y.K.; Yu, Y.G. Bacterially expressed human serotonin receptor $3 \mathrm{~A}$ is functionally reconstituted in proteoliposomes. Protein Expr. Purif. 2013, 88, 190-195. [CrossRef]

136. Jung, Y.; Jung, H.; Lim, D. Bacteriophage membrane protein P9 as a fusion partner for the efficient expression of membrane proteins in Escherichia coli. Protein Expr. Purif. 2015, 116, 12-18. [CrossRef] [PubMed]

137. Myhrvold, C.; Polka, J.K.; Silver, P.A. Synthetic lipid-containing scaffolds enhance production by colocalizing enzymes. ACS Synth. Biol. 2016, 5, 1396-1403. [CrossRef] [PubMed]

138. Pawlowski, A.; Moilanen, A.M.; Rissanen, I.A.; Määttä, J.A.; Hytönen, V.P.; Ihalainen, J.A.; Bamford, J.K. The minor capsid protein VP11 of thermophilic bacteriophage P23-77 facilitates virus assembly by using lipid-protein interactions. J. Virol. 2015, 89, 7593-7603. [CrossRef]

(C) 2019 by the authors. Licensee MDPI, Basel, Switzerland. This article is an open access article distributed under the terms and conditions of the Creative Commons Attribution (CC BY) license (http:/ / creativecommons.org/licenses/by/4.0/). 